\title{
Influence of Underlying Diseases and Age on the Association between Obesity and All-Cause Mortality in Post-Middle Age
}

\author{
Kazuki Yoshimoto, Tatsuya Noda, Tomoaki Imamura \\ Department of Public Health, Health Management and Policy, Nara Medical University, Nara, Japan \\ Email: yoshimotok@naramed-u.ac.jp
}

How to cite this paper: Yoshimoto, K., Noda, T., and Imamura, T. (2018) Influence of Underlying Diseases and Age on the Association between Obesity and All-Cause Mortality in Post-Middle Age. Health, 10, 1171-1184.

https://doi.org/10.4236/health.2018.109089

Received: August 9, 2018

Accepted: September 8, 2018

Published: September 11, 2018

Copyright (C) 2018 by authors and Scientific Research Publishing Inc. This work is licensed under the Creative Commons Attribution International License (CC BY 4.0).

http://creativecommons.org/licenses/by/4.0/

(c) (i) Open Access

\begin{abstract}
Background: Studies on the association between obesity and all-cause mortality have found that the degree of obesity is directly proportional to all-cause mortality. In contrast, there have been studies indicating that obese people with underlying diseases have a higher survival rate. We hypothesized that age and underlying diseases lead to such contrasting results. Therefore, we conducted a study to clarify the influence of post-middle age obesity and underlying diseases on all-cause mortality. Methods: This study used data from longitudinal studies in the United States, which conducted follow-up for 19 years on 33,708 participants in different age groups: $\geq 45,45-64$, and $\geq 65$ years. Hazard ratio (HR) was determined using the Cox proportional hazards model to analyze a group consisting of all participants, a group of those with underlying diseases, and a group of those without underlying diseases, considering age, gender, education history, marital status, household income, smoking history, and BMI category as covariates. Results: In the group aged $\geq 65$ without underlying diseases, HR was almost 1 in those with BMI 25 $<30,30-<35$, and BMI $>35 \mathrm{~kg} / \mathrm{m}^{2}$. Further, HR was higher in the $45-64$ age group without underlying diseases if BMI was $>35 \mathrm{~kg} / \mathrm{m}^{2}$. However, HR was approximately 1 in the $\geq 65$ age group. Conclusions: The study revealed that among individuals aged $\geq 65$ years without underlying diseases, there was no association between obesity and all-cause mortality. Among individuals without underlying diseases, HR was higher in the $45-64$ age group with BMI > $35 \mathrm{~kg} / \mathrm{m}^{2}$ but was approximately 1 among those aged $\geq 65$ years. Therefore, an interaction based on age was detected. These findings may lead to recommendations regarding the need to modify the advice and education provided to obese individuals in different age groups.
\end{abstract}

\section{Keywords}

Underlying Diseases, Obesity, All-Cause Mortality, Post-Middle Age 


\section{Introduction}

Approximately one-third of the world's population is considered obese. In particular, the number of obese people is known to be increasing in high-income countries in North America and Europe [1] [2] [3] [4]. Because obesity is thought to increase the risk of underlying diseases [5]-[13], maintaining average body proportion and avoiding obesity are important issues in health maintenance.

Several studies have indicated that a greater degree of obesity correlates with higher all-cause mortality [14]-[27]. On the other hand, obese individuals with diseases such as heart failure and hypertension have been reported to have a higher survival rate than non-obese individuals [28]-[37]. Because mortality among young obese individuals is higher than that among elderly obese individuals [38] [39], age has also been reported to influence the association between obesity and all-cause mortality rate.

Differing results in obesity and all-cause mortality studies may be due to differences in target populations or bias correction methods such as inclusion and exclusion criteria set at the start of the studies [40]. However, details of the influence of different criteria and conditions on results of studies have not been clarified. In this study, we focused on age and underlying diseases as conditions that can affect results regarding correlations between Body Mass Index (BMI), which represents the degree of obesity, and all-cause mortality rate, with the aim of clarifying the influence of post-middle age obesity and underlying diseases on all-cause mortality rate. Most of the previous work on the relationship between obesity and all-cause mortality used a survival analysis such as the Cox proportional hazard model. Therefore, also in this study, the relationship between obesity and all-cause mortality was analyzed using the Cox proportional hazard model.

\section{Methods}

\subsection{About HRS Data}

The Health and Retirement Study (HRS) is a nationally representative elderly panel survey led by Michigan University sampled using a multi-stage extraction method focused on American nationals aged $\geq 50$ years including a total of 37,000 people from 23,000 households in the United States. With the aim to understand the actual living conditions of the elderly, data were collected every 2 years since 1992, and the survey had been conducted for a total of 11 times up to 2012.

HRS data obtained over a long period were gathered. An initial HRS cohort data of 1992 consisted of individuals born between 1931 and 1941 (aged 51 - 61 years at the time of the study) and their spouses. Next, using data from the "AHEAD" study, which was conducted separately from HRS, cohort data of those born between 1890 and 1923 (aged $\geq 70$ years) was integrated into the HRS data in 1998. HRS incorporated 2 new cohort data sets, one of those born between 1924 and 1930 and the other of those born between 1942 and 1947, with the goal to create a complete sample data set of American populations aged $\geq 50$ 
years. Further, HRS incorporated additional data as follows: in 1998, data of those born between 1942 and 1947; in 2004, data of those born between 1948 and 1953; and in 2010, data of those born between 1954 and 1959.

\subsection{Ethical Considerations}

The HRS data that we used for our analysis was collected from 37,317 people between 1992 and 2012 who agreed to participate in the study via informed consent after approval from the University of Michigan Ethics Committee (IRB) was obtained. The HRS data is available for public use via web-based access following the instructions provided on the HRS website (hrsonline.isr.umich.edu/index.php). Although there are some restrictions on the answers to sensitive and restricted questionnaires, data are made available based on appropriate procedures. For the present study, we applied for data user registration on the HRS website and obtained approval to use the data from the HRS group. Thereafter, we were provided publicly available data files that we used to perform our analysis.

\subsection{Subjects and Variables}

Among 37,317 individuals who participated in HRS between 1992 and 2012, those aged $\geq 45$ years were chosen as study subjects. To compare the subjects with and without underlying diseases, those who suffered from at least 1 of 6 chronic diseases, diabetes mellitus, chronic respiratory disease, chronic heart disease, malignant tumors, high blood pressure, or stroke, were identified as a group with underlying diseases. Those who denied having any of the above 6 diseases at study initiation were identified as a group without underlying diseases. Analysis was performed on the following groups: all participants, a group with underlying diseases, and a group without underlying diseases. Subjects were also stratified into different age groups comprising those aged $\geq 45,45$ - 64 (middle-aged and above), and $\geq 65$ (the elderly).

The degree of obesity is defined by WHO standards [41] as follows: underweight $\left(B M I<18.5 \mathrm{~kg} / \mathrm{m}^{2}\right.$ ), normal range (BMI $\left.18.5-<25 \mathrm{~kg} / \mathrm{m}^{2}\right)$, pre-obese (BMI $25-<30 \mathrm{~kg} / \mathrm{m}^{2}$ ), class I obese (BMI $30-<35 \mathrm{~kg} / \mathrm{m}^{2}$ ), class II obese (BMI 35 $\left.-<40 \mathrm{~kg} / \mathrm{m}^{2}\right)$, and class III obese (BMI $\left.\geq 40 \mathrm{~kg} / \mathrm{m}^{2}\right)$. We stratified the participants into 6 groups based on the WHO criteria of degree of obesity: BMI $<18.5 \mathrm{~kg} / \mathrm{m}^{2}$, BMI 18.5 - $<22.5 \mathrm{~kg} / \mathrm{m}^{2}$, BMI $22.5-<25 \mathrm{~kg} / \mathrm{m}^{2}$, BMI $25-<30 \mathrm{~kg} / \mathrm{m}^{2}$, BMI $30-$ $<35 \mathrm{~kg} / \mathrm{m}^{2}$, and BMI $\geq 35 \mathrm{~kg} / \mathrm{m}^{2}$. BMI $22.5-<25 \mathrm{~kg} / \mathrm{m}^{2}$, which was associated with the lowest mortality rate, was defined as a reference based on a previous study that involved data of 900,000 individuals [18] and one that was conducted on the data of 30,300,000 individuals [26]. The variables were as follows: age at baseline, gender (male or female), race (white or nonwhite), education history (high school/higher graduate or less than a high school education), marital status (married/de factor relationship or unmarried), household income (annual household income $\geq \$ 30,000$ or $<\$ 30,000$ ), smoking history (with or without smoking history), BMI (BMI $<18.5 \mathrm{~kg} / \mathrm{m}^{2}$, BMI $18.5-<22.5 \mathrm{~kg} / \mathrm{m}^{2}$, BMI 22.5 - 
$<25 \mathrm{~kg} / \mathrm{m}^{2}$, BMI $25-<30 \mathrm{~kg} / \mathrm{m}^{2}$, BMI $30-<35 \mathrm{~kg} / \mathrm{m}^{2}$, and BMI $\left.\geq 35 \mathrm{~kg} / \mathrm{m}^{2}\right)$, and underlying diseases (with or without underlying diseases). Subjects were excluded from the study if any information was missing regarding age, gender, race, educational history, marital status, annual household income, smoking history, BMI, or disease morbidity, or if they were aged $\leq 44$ at the start of the study. Because data from the National Death Index up to 2011 obtained by the RAND Institute was used to track the death year, the follow-up period of this study was 19 years, from 1992 to 2011. In addition, HRS data and those preprocessed by the RAND Institute were used.

\subsection{Exclusion Period}

To exclude individuals who died from rapid deterioration in their condition soon after study participation or those who were already in a poor condition, those who died within 2 years after study participation were excluded.

\subsection{Statistical Analysis}

Using the Cox proportional hazards model, the hazard ratio (HR) and $95 \%$ confidence intervals $(95 \% \mathrm{CI})$ were calculated for the BMI categories using all-cause mortality as an outcome. In the analysis, age, sex, race, marital status, educational history, household income, smoking history, BMI category were included as covariates. A univariate analysis was performed for each variable. Cross tables were prepared for variables, and associations between the variables were examined using the chi-square test. For variables with strong relevance between variables, an interaction term was created; this term was used as an adjustment variable. In addition, proportional hazards of each variable were confirmed to be maintained using log-log plot survival curves. Covariates and interaction terms were introduced in the Cox proportional hazards model, and HR was obtained while confirming the impact of HR between variables.

The software package JMP Pro11.2 (SAS Institute Inc., Cary, NC, USA) was used for analysis. SPSS20.0 (SPSS Inc., Chicago, IL, USA) was used for plotting log-log survival curves that could not be analyzed using JMP Pro11.2.

The general form of the cox proportional hazards model was:

$$
h(t ; x)=h_{0}(t) \cdot \exp \left(\beta_{1} x_{1}+\cdots+\beta \text { pxp }\right)
$$

where $h(t)$ is the hazard function at time $\mathrm{t}$ for a subject with covariate values $x_{1}, \ldots x_{p}, h_{0}(t)$ is the baseline hazard function, i.e., the hazard function when all covariates equal zero. exp is the exponential function $\left(\exp (x)=\mathrm{e}^{\mathrm{x}}\right), x_{i}$ is the $i^{\text {th }}$ covariate in the model, and $\beta_{i}$ is the regression coefficient for the $i^{\text {th }}$ covariate, $x_{i}$.

For a single dichotomous covariate, such as values $j$ and $i$, the hazard ratio (HR) was

$$
\begin{aligned}
H R & =\frac{h(t ; x i)}{h(t ; x j)}=\frac{h_{0}(t) \exp \{\beta 1 x i 1+\ldots+\beta p x i p\}}{h_{0}(t) \exp \{\beta 1 x j 1+\ldots+\beta p x j p\}} \\
& =\exp \{\beta 1(x i 1-x j 1)+\ldots+\beta p(x i p-x j p)\}
\end{aligned}
$$


HR does not depend on time and is always constant.

\section{Results}

Demographic features of the study participants are shown in Table 1.

The number of participants aged $\geq 45$ years excluding those who died within 2 years after the start of the study was 33,708, and females accounted for $56 \%$ of all participants. The median age was 56 years, and the mean age was 60.14 years. The median BMI was $26.6 \mathrm{~kg} / \mathrm{m}^{2}$, and the mean BMI was $27.45 \mathrm{~kg} / \mathrm{m}^{2}$. During the 19 years of follow-up, the observation period was 335,219 person years and the mean follow-up period was 9.94 years. The number of deaths during the follow-up period was 10,104 , and the mean follow-up period only for death events was 9.91 years. The mean follow-up period from the start of the study until death of the 6942 individuals who had at least one underlying disease and were aged $\geq 45$ years was 9.46 years, and the mean follow-up period from the start of the study until death of the 3162 individuals without underlying diseases and were aged $\geq 45$ years was 10.9 years (Table 2 ).

The number of participants aged 45 - 64 years excluding those who died within 2 years after the start of the study was 23,730, and females accounted for $54 \%$ of all participants. The median age was 54 years, and the mean age was 54.02 years. The median BMI was $27.1 \mathrm{~kg} / \mathrm{m}^{2}$, and the mean BMI was 28.04 $\mathrm{kg} / \mathrm{m}^{2}$. During the 19 years of follow-up, the observation period was 234,192 person years and the mean follow-up period was 9.87 years. The number of deaths during the follow-up period was 3556, and the mean follow-up period only for death events was 11.51 years. The mean follow-up period until death of the 2281 individuals aged 45 - 64 years who had at least one underlying disease was 11.02 years, and the mean follow-up period of the 1275 individuals without underlying diseases was 12.38 years (Table 3 ).

The number of participants aged $\geq 65$ years excluding those who died within 2 years after the start of the study was 9978 , and females accounted for $59 \%$ of all participants. The median age was 73 years, and the mean age was 74.7 years. The median BMI was $25.6 \mathrm{~kg} / \mathrm{m}^{2}$, and the mean BMI was $26.05 \mathrm{~kg} / \mathrm{m}^{2}$. During the 19 years of follow-up, the observation period was 101,027 person years and the mean follow-up period was 10.12 years. The number of deaths during the follow-up period was 6548, and the mean follow-up period only for death events was 9.04 years. The mean follow-up period until death of the 4661 individuals aged $\geq 65$ years who had at least one underlying disease was 8.69 years, and the mean follow-up period of the 1887 individuals without underlying diseases was 9.9 years (Table 4 ).

An interaction term was created for each variable among age, gender, race, education history, marital status, household income, smoking history, and BMI categories that showed association using chi-square test and was input as a covariate in the Cox proportional hazards model. No results showed that HR was significantly influenced before and after input of the interaction term. In addition, the proportional hazards for each variable could be confirmed. 
Table 1. Sociodemographic characteristics.

\begin{tabular}{|c|c|c|c|c|c|c|c|c|c|c|c|c|c|c|c|c|c|c|}
\hline & \multicolumn{6}{|c|}{$\geq 45$ years old } & \multicolumn{6}{|c|}{45 - 64 years old } & \multicolumn{6}{|c|}{$\geq 65$ years old } \\
\hline & \multicolumn{2}{|c|}{$\begin{array}{c}\text { All } \\
\text { participants } \\
\mathrm{N}=33,708\end{array}$} & \multicolumn{2}{|c|}{$\begin{array}{c}\text { Underlying } \\
\text { disease } \\
\mathrm{N}=18,006\end{array}$} & \multicolumn{2}{|c|}{$\begin{array}{c}\text { Without } \\
\text { underlying } \\
\text { diseases } \\
\mathrm{N}=15,702\end{array}$} & \multicolumn{2}{|c|}{$\begin{array}{c}\text { All } \\
\text { participants } \\
\mathrm{N}=23,730\end{array}$} & \multicolumn{2}{|c|}{$\begin{array}{c}\text { Underlying } \\
\text { disease } \\
\mathrm{N}=11,338\end{array}$} & \multicolumn{2}{|c|}{$\begin{array}{c}\text { Without } \\
\text { underlying } \\
\text { diseases } \\
\mathrm{N}=12,392\end{array}$} & \multicolumn{2}{|c|}{$\begin{array}{c}\text { All } \\
\text { participants } \\
\mathrm{N}=9978\end{array}$} & \multicolumn{2}{|c|}{$\begin{array}{c}\text { Underlying } \\
\text { disease } \\
\mathrm{N}=6668\end{array}$} & \multicolumn{2}{|c|}{$\begin{array}{c}\text { Without } \\
\text { underlying } \\
\text { diseases } \\
\mathrm{N}=3310\end{array}$} \\
\hline & $\mathrm{n}$ & $\%$ & $\mathrm{n}$ & $\%$ & $\mathrm{n}$ & $\%$ & $\mathrm{n}$ & $\%$ & $\mathrm{n}$ & $\%$ & $\mathrm{n}$ & $\%$ & $\mathrm{n}$ & $\%$ & $\mathrm{n}$ & $\%$ & $\mathrm{n}$ & $\%$ \\
\hline \multicolumn{19}{|l|}{ Gender } \\
\hline Female & 18,754 & 56 & 9906 & 55 & 8848 & 56 & 12,834 & 54 & 6031 & 53 & 6803 & 55 & 5920 & 59 & 3875 & 58 & 2045 & 62 \\
\hline Male & 14,954 & 44 & 8100 & 45 & 6854 & 44 & 10,896 & 46 & 5307 & 47 & 5589 & 45 & 4058 & 41 & 2793 & 42 & 1265 & 38 \\
\hline \multicolumn{19}{|l|}{ Race } \\
\hline Non-white & 8191 & 24 & 5021 & 28 & 3170 & 20 & 6668 & 28 & 3944 & 35 & 2724 & 22 & 1523 & 15 & 1077 & 16 & 446 & 14 \\
\hline White & 25,517 & 76 & 12,985 & 72 & 12,532 & 80 & 17,062 & 72 & 7394 & 65 & 9668 & 78 & 8455 & 85 & 5591 & 84 & 2864 & 86 \\
\hline \multicolumn{19}{|l|}{$\begin{array}{c}\text { Education } \\
\text { history }\end{array}$} \\
\hline \multicolumn{19}{|l|}{ Less than a high } \\
\hline $\begin{array}{l}\text { school } \\
\text { education }\end{array}$ & 7916 & 23 & 3631 & 20 & 4285 & 27 & 6348 & 27 & 2657 & 23 & 3691 & 30 & 1568 & 16 & 974 & 15 & 594 & 18 \\
\hline $\begin{array}{l}\text { High school/ } \\
\text { higher graduate }\end{array}$ & 25,792 & 77 & 14,375 & 80 & 11417 & 73 & 17,382 & 73 & 8681 & 77 & 8701 & 70 & 8410 & 84 & 5694 & 85 & 2716 & 82 \\
\hline \multicolumn{19}{|l|}{ Marital status } \\
\hline Unmarried & 9414 & 28 & 5667 & 31 & 3747 & 24 & 5575 & 23 & 3074 & 27 & 2501 & 20 & 3839 & 38 & 2593 & 39 & 1246 & 38 \\
\hline \multicolumn{19}{|l|}{$\begin{array}{l}\text { Annual } \\
\text { household } \\
\text { income }\end{array}$} \\
\hline$<\$ 30000$ & 15,071 & 45 & 9199 & 51 & 5872 & 37 & 8273 & 35 & 4563 & 40 & 3710 & 30 & 6798 & 68 & 4636 & 70 & 2162 & 65 \\
\hline$\geq \$ 30000$ & 18,637 & 55 & 8807 & 49 & 9830 & 63 & 15,457 & 65 & 6775 & 60 & 8682 & 70 & 3180 & 32 & 2032 & 30 & 1148 & 35 \\
\hline \multicolumn{19}{|l|}{ Smoking history } \\
\hline $\begin{array}{c}\text { Without } \\
\text { smoking history }\end{array}$ & 14,089 & 42 & 7236 & 40 & 6853 & 44 & 9492 & 40 & 4265 & 38 & 5227 & 42 & 4597 & 46 & 2971 & 45 & 1626 & 49 \\
\hline $\begin{array}{l}\text { With smoking } \\
\text { history }\end{array}$ & 19,619 & 58 & 10,770 & 60 & 8849 & 56 & 14,238 & 60 & 7073 & 62 & 7165 & 58 & 5381 & 54 & 3697 & 55 & 1684 & 51 \\
\hline \multicolumn{19}{|l|}{ BMI category } \\
\hline$<18.5$ & 504 & 1 & 270 & 2 & 234 & 1 & 255 & 1 & 110 & 1 & 145 & 1 & 249 & 3 & 160 & 2 & 89 & 3 \\
\hline $18.5-<22.5$ & 4759 & 14 & 1940 & 11 & 2819 & 18 & 2982 & 13 & 899 & 8 & 2083 & 17 & 1777 & 18 & 1041 & 16 & 736 & 22 \\
\hline $22.5-<25$ & 6355 & 19 & 2938 & 16 & 3417 & 22 & 4075 & 17 & 1470 & 13 & 2605 & 21 & 2280 & 23 & 1468 & 22 & 812 & 25 \\
\hline $25-<30$ & 13,262 & 39 & 6986 & 39 & 6276 & 40 & 9282 & 39 & 4286 & 38 & 4996 & 40 & 3980 & 40 & 2700 & 40 & 1280 & 39 \\
\hline $30-<35$ & 5812 & 17 & 3657 & 20 & 2155 & 14 & 4532 & 19 & 2687 & 24 & 1845 & 15 & 1280 & 13 & 970 & 15 & 310 & 9 \\
\hline$\geq 35$ & 3016 & 9 & 2215 & 12 & 801 & 5 & 2604 & 11 & 1886 & 17 & 718 & 6 & 412 & 4 & 329 & 5 & 83 & 3 \\
\hline
\end{tabular}

*Exclude those who died within 2 years of starting tracking. 
Table 2. BMI category for those $\geq 45$ years old and HR for all-cause mortality.

\begin{tabular}{|c|c|c|c|c|c|c|c|c|c|c|c|c|}
\hline & \multicolumn{4}{|c|}{$\geq 45$ years; all participants } & \multicolumn{4}{|c|}{$\begin{array}{l}\geq 45 \text { years; those with } \\
\text { underlying disease }\end{array}$} & \multicolumn{4}{|c|}{$\begin{array}{c}\geq 45 \text { years; those without } \\
\text { underlying disease }\end{array}$} \\
\hline $\begin{array}{l}\text { follow-up period } \\
\text { (year) }\end{array}$ & \multicolumn{4}{|c|}{9.94} & \multicolumn{4}{|c|}{9.11} & \multicolumn{4}{|c|}{10.9} \\
\hline $\begin{array}{l}\text { The mean } \\
\text { follow-up period } \\
\text { until death }\end{array}$ & \multicolumn{4}{|c|}{9.91} & \multicolumn{4}{|c|}{9.46} & \multicolumn{4}{|c|}{10.9} \\
\hline \multirow[t]{2}{*}{$\begin{array}{l}\text { All participants/ } \\
\text { death }(\mathrm{N})\end{array}$} & \multicolumn{4}{|c|}{$33,708 / 10,104$} & \multicolumn{4}{|c|}{$18,006 / 6942$} & \multicolumn{4}{|c|}{$15,702 / 3162$} \\
\hline & $\mathrm{n}$ & $\begin{array}{l}\text { No. of } \\
\text { deaths }\end{array}$ & HR & $95 \% \mathrm{CI}$ & n & $\begin{array}{l}\text { No. of } \\
\text { deaths }\end{array}$ & HR & $95 \% \mathrm{CI}$ & $\mathbf{n}$ & $\begin{array}{l}\text { No. of } \\
\text { deaths }\end{array}$ & HR & $95 \% \mathrm{CI}$ \\
\hline \multicolumn{13}{|l|}{ BMI category } \\
\hline-18.5 & 504 & 279 & 1.72 & $(1.51-1.95)^{*}$ & 270 & 182 & 1.84 & $(1.57-2.15)^{*}$ & 234 & 97 & 1.71 & $(1.37-2.11)^{*}$ \\
\hline $18.5-22.5$ & 4759 & 1738 & 1.17 & $(1.1-1.25)^{*}$ & 1940 & 1044 & 1.20 & $(1.10-1.30)^{*}$ & 2819 & 694 & 1.23 & $(1.11-1.37)^{*}$ \\
\hline $22.5-25$ & 6355 & 2126 & 1.00 & (ref) & 2938 & 1397 & 1.00 & (ref) & 3417 & 729 & 1.00 & (ref) \\
\hline $25-30$ & 13,262 & 3937 & 0.96 & $(0.91-1.01)$ & 6986 & 2733 & 0.90 & $(0.85-0.96)^{*}$ & 6276 & 1204 & 0.95 & $(0.87-1.05)$ \\
\hline $30-35$ & 5812 & 1382 & 1.00 & $(0.94-1.08)$ & 3657 & 1053 & 0.88 & $(0.81-0.95)^{*}$ & 2155 & 329 & 1.00 & $(0.87-1.13)$ \\
\hline $35-$ & 3016 & 642 & 1.45 & $(1.32-1.58)^{*}$ & 2215 & 533 & 1.20 & $(1.08-1.33)^{*}$ & 801 & 109 & 1.30 & $(1.05-1.58)^{*}$ \\
\hline
\end{tabular}

Statistically Significant *, Within 2 years from commencement of tracking Exclusion from death, Covariates; Age, gender, race, marital status, academic background, annual household income, smoking history, BMI category.

Table 3. BMI category 45 - 64 years old and HR for all-cause mortality.

\begin{tabular}{|c|c|c|c|c|c|c|c|c|c|c|c|c|}
\hline & \multicolumn{4}{|c|}{$\begin{array}{l}45 \text { - } 64 \text { years; } \\
\text { all participants }\end{array}$} & \multicolumn{4}{|c|}{$\begin{array}{l}45 \text { - } 64 \text { years; with } \\
\text { underlying disease }\end{array}$} & \multicolumn{4}{|c|}{$\begin{array}{l}45 \text { - } 64 \text { years; } \\
\text { without underlying disease }\end{array}$} \\
\hline $\begin{array}{l}\text { The mean follow-up } \\
\text { period (year) }\end{array}$ & \multicolumn{4}{|c|}{9.87} & \multicolumn{4}{|c|}{8.87} & \multicolumn{4}{|c|}{10.78} \\
\hline $\begin{array}{l}\text { The mean follow-up } \\
\text { period until death }\end{array}$ & \multicolumn{4}{|c|}{11.51} & \multicolumn{4}{|c|}{11.02} & \multicolumn{4}{|c|}{12.38} \\
\hline \multirow[t]{2}{*}{$\begin{array}{l}\text { All participants/ } \\
\text { death }(\mathrm{N})\end{array}$} & \multicolumn{4}{|c|}{$23,730 / 3556$} & \multicolumn{4}{|c|}{$11,338 / 2281$} & \multicolumn{4}{|c|}{$12,392 / 1275$} \\
\hline & $\mathbf{n}$ & $\begin{array}{l}\text { No. of } \\
\text { deaths }\end{array}$ & $\mathrm{HR}$ & $95 \% \mathrm{CI}$ & $\mathrm{n}$ & $\begin{array}{l}\text { No. of } \\
\text { deaths }\end{array}$ & HR & $95 \% \mathrm{CI}$ & $\mathbf{n}$ & $\begin{array}{l}\text { No. of } \\
\text { deaths }\end{array}$ & HR & $95 \% \mathrm{CI}$ \\
\hline \multicolumn{13}{|l|}{ BMI category } \\
\hline-18.5 & 255 & 74 & 2.69 & $(2.09-3.40)^{*}$ & 110 & 46 & 2.94 & $(2.13-3.97)^{*}$ & 145 & 28 & 2.44 & $(1.61-3.55)^{\star}$ \\
\hline $18.5-22.5$ & 2982 & 473 & 1.20 & $(1.06-1.36)^{*}$ & 899 & 240 & 1.25 & $(1.05-1.47)^{\star}$ & 2083 & 233 & 1.28 & $(1.07-1.52)^{*}$ \\
\hline $22.5-25$ & 4075 & 597 & 1.00 & (ref) & 1470 & 332 & 1.00 & (ref) & 2605 & 265 & 1.00 & (ref) \\
\hline $25-30$ & 9282 & 1408 & 1.02 & $(0.92-1.12)$ & 4286 & 894 & 0.89 & $(0.79-1.02)$ & 4996 & 514 & 1.00 & $(0.86-1.16)$ \\
\hline $30-35$ & 4532 & 615 & 1.10 & $(0.98-1.23)$ & 2687 & 447 & 0.87 & $(0.75-1.00)$ & 1845 & 168 & 1.06 & $(0.87-1.29)$ \\
\hline $35-$ & 2604 & 389 & 1.75 & $(1.54-1.99)^{*}$ & 1886 & 322 & 1.26 & $(1.08-1.47)^{*}$ & 718 & 67 & 1.57 & $(1.19-2.04)^{*}$ \\
\hline
\end{tabular}

Statistically Significant *, Within 2 years from commencement of tracking Exclusion from death, Covariates; Age, gender, race, marital status, academic background, annual household income, smoking history, BMI category. 
Table 4. BMI category for those $\geq 65$ years old and HR for all-cause mortality.

\begin{tabular}{|c|c|c|c|c|c|c|c|c|c|c|c|c|}
\hline & \multicolumn{4}{|c|}{$\geq 65$ years; all participants } & \multicolumn{4}{|c|}{$\geq 65$ years; underlying disease } & \multicolumn{4}{|c|}{$\geq 65$ years; without underlying disease } \\
\hline $\begin{array}{l}\text { The mean follow-up } \\
\text { period (year) }\end{array}$ & \multicolumn{4}{|c|}{10.12} & \multicolumn{4}{|c|}{9.52} & \multicolumn{4}{|c|}{11.3} \\
\hline $\begin{array}{l}\text { The mean follow-up } \\
\text { period until death }\end{array}$ & \multicolumn{4}{|c|}{9.04} & \multicolumn{4}{|c|}{8.69} & \multicolumn{4}{|c|}{9.9} \\
\hline \multirow[t]{2}{*}{$\begin{array}{l}\text { All participants/ } \\
\text { death }(\mathrm{N})\end{array}$} & \multicolumn{4}{|c|}{$9978 / 6548$} & \multicolumn{4}{|c|}{$6668 / 4661$} & \multicolumn{4}{|c|}{$3310 / 1887$} \\
\hline & $\mathbf{n}$ & $\begin{array}{l}\text { No. of } \\
\text { deaths }\end{array}$ & HR & $95 \% \mathrm{CI}$ & $\mathbf{n}$ & $\begin{array}{l}\text { No. of } \\
\text { deaths }\end{array}$ & HR & $95 \%$ CI & $\mathbf{n}$ & $\begin{array}{l}\text { No. of } \\
\text { deaths }\end{array}$ & HR & $95 \% \mathrm{CI}$ \\
\hline \multicolumn{13}{|l|}{ BMI category } \\
\hline-18.5 & 249 & 205 & 1.50 & $(1.29-1.74)^{*}$ & 160 & 136 & 1.60 & $(1.33-1.91)^{*}$ & 89 & 69 & 1.47 & $(1.13-1.89)^{*}$ \\
\hline $18.5-22.5$ & 1777 & 1265 & 1.15 & $(1.07-1.24)^{*}$ & 1041 & 804 & 1.18 & $(1.07-1.29)^{*}$ & 736 & 461 & 1.18 & $(1.04-1.35)^{*}$ \\
\hline $22.5-25$ & 2280 & 1529 & 1.00 & (ref) & 1468 & 1065 & 1.00 & (ref) & 812 & 464 & 1.00 & (ref) \\
\hline $25-30$ & 3980 & 2529 & 0.94 & $(0.88-1.00)^{*}$ & 2700 & 1839 & 0.92 & $(0.85-0.99)^{*}$ & 1280 & 690 & 0.93 & $(0.82-1.04)$ \\
\hline $30-35$ & 1280 & 767 & 0.97 & $(0.89-1.06)$ & 970 & 606 & 0.91 & $(0.82-1.01)$ & 310 & 161 & 0.96 & $(0.80-1.14)$ \\
\hline $35-$ & 412 & 253 & 1.22 & $(1.07-1.39)^{*}$ & 329 & 211 & 1.16 & $(1.00-1.34)$ & 83 & 42 & 1.04 & $(0.75-1.41)$ \\
\hline
\end{tabular}

Statistically Significant *, Within 2 years from commencement of tracking Exclusion from death, Covariates; Age, gender, race, marital status, academic background, annual household income, smoking history, BMI category.

In each age group ( $\geq 45,45-64$, and $\geq 65$ years), the Cox proportional hazards model was used to analyze a group comprising all subjects, a group with underlying diseases, and a group without underlying diseases, considering age, gender, race, education history, marital status, household income, smoking history, and BMI category as variables. BMI $22.5-25 \mathrm{~kg} / \mathrm{m}^{2}$ was set as a reference, and HR of the BMI category with $95 \%$ CI were calculated. The results showed that in the groups comprising all subjects, with underlying diseases, and without underlying diseases, HR was high if BMI was $<18.5 \mathrm{~kg} / \mathrm{m}^{2}$, and individuals with BMI $18.5-22.5 \mathrm{~kg} / \mathrm{m}^{2}$ who were relatively slim also had a slightly high HR. The 45 - 64 age group showed a higher HR than the $\geq 65$ age group if BMI was $<18.5 \mathrm{~kg} / \mathrm{m}^{2}$.

All-subject groups aged $45-64$ years had a HR $>1$ if BMI was $30-<35 \mathrm{~kg} / \mathrm{m}^{2}$ or $>35 \mathrm{~kg} / \mathrm{m}^{2}$, and there was an association between obesity and all-cause mortality, but in all-subject groups aged $\geq 65$ years; this association was found only if BMI was $>35 \mathrm{~kg} / \mathrm{m}^{2}$. Further, in any age group with underlying diseases, groups with BMI $25-<30 \mathrm{~kg} / \mathrm{m}^{2}$ or $30-<35 \mathrm{~kg} / \mathrm{m}^{2}$ had $\mathrm{HR}<1$, but if BMI was $>35$ $\mathrm{kg} / \mathrm{m}^{2}$, HR was $>1$, indicating an association between obesity and all-cause mortality.

However, in the subject groups aged $\geq 65$ years without underlying diseases, with BMI $25-<30 \mathrm{~kg} / \mathrm{m}^{2}$, BMI $30-<35 \mathrm{~kg} / \mathrm{m}^{2}$, or BMI $>35 \mathrm{~kg} / \mathrm{m}^{2}$, HR was close to 1 and there was no association between obesity and all-cause mortality. 


\section{Discussion}

In the present study, over a 19-year follow-up period, subjects in age groups of $\geq 45,45-64$, and $\geq 65$ years were further grouped into subgroups comprising all subjects, those with underlying diseases, and those without underlying diseases. Covariates were used in a Cox proportional hazards model, and HR of each BMI category was calculated. The results revealed that in the group without underlying diseases, a characteristic association was noted between mortality and obesity in individuals aged $45-64$ and $\geq 65$ years.

Studies on the association between smoking history and all-cause mortality comparing healthy individuals without underlying diseases and those with underlying diseases have shown that healthy obese individuals who had neither a smoking history nor underlying diseases had higher all-cause mortality rates than obese individuals with a smoking history and underlying diseases [15] [19] [25] [26]. In the present study, individuals aged $\geq 45$ and 45 - 64 years, individuals without underlying diseases with BMI $25-<30,30-<35$, or $>35 \mathrm{~kg} / \mathrm{m}^{2}$ had higher all-cause mortality rates than those with underlying diseases, which is consistent with previous studies. Despite the fact that previous studies have concluded that adjustment or exclusion of bias due to diseases was not effective when studying the association between obesity and all-cause mortality [23] [42] [43], the present study revealed that the association between obesity and all-cause mortality rate differs depending on the presence or absence of underlying diseases. This appears to confirm the necessity of adjusting for the influence of underlying diseases.

There have been reports that obese adults have higher all-cause mortality rates than the obese elderly [14] [38] and that mortality rates among the obese elderly are lower than those among obese youth [39]. Previous studies have demonstrated that age influences the association between obesity and all-cause mortality rates. However, we were unable to find any study that has analyzed the association between obesity and all-cause mortality rate focusing on underlying diseases and age. As we hypothesized that obesity and all-cause mortality may have an interaction based on age, we analyzed individuals aged 45 - 64 and $\geq 65$ years in groups comprising all subjects, with underlying diseases, and without underlying diseases. The results indicated that in the all-subject group and in that with underlying diseases, individuals aged $\geq 65$ years are likely to exhibit a weaker association between obesity with BMI of $\geq 35 \mathrm{~kg} / \mathrm{m}^{2}$ and all-cause mortality than those aged 45 - 64 years. Previous studies have reported that among individuals aged $\geq 65$, there is no association between obesity and the all-cause mortality rate [44] [45] [46]; however, none of these studies mentioned the influence of underlying diseases. In our study, the group without underlying diseases with BMI > $35 \mathrm{~kg} / \mathrm{m}^{2}$ had a relatively high HR among those aged $45-64$ years but had an HR of approximately 1 among those aged $\geq 65$ years. This clearly indicated that age-related interactions were noted in obese individuals aged $45-64$ years without underlying diseases and obese individuals aged $\geq 65$ years without un- 
derlying diseases. Because obesity increases the all-cause mortality rate, health professionals need to provide health advice and education to obese individuals. The present study suggested that such advice and education should be modified depending on the age of the individuals.

In the present study, questionnaire items were based on self-reported status of underlying diseases, height, weight, and BMI, which may have led to the underestimation of obesity [47]. While this study used self-reported BMI, because it has been reported that there is no significant difference between accurate BMI and self-reported BMI [48], we believe that the results of this study are sufficiently reliable.

In addition, because the mean BMI among Americans is much higher than the BMI defined by WHO as being normal, it is possible that BMI ranges in other nations may greatly differ from those among Americans. Due to a lack of information regarding muscle amount, it was impossible to distinguish between those with a large number of fat cells and those with significant muscle mass, and we were unable to exclude individuals who were not obese despite having a high BMI. Further, as neither the status of underlying diseases that occurred after the study started nor the rate of medical examinations was known, it was not clear whether a person was healthy and obese or was obese with underlying diseases. Moreover, as this study was performed in one country, the results may be different from those of other countries. Despite the above limitations, we consider the outcomes of the present study to be useful in creating strategies and content for health education and management among middle-aged and above obese individuals.

The results of the present study revealed that among obese individuals without underlying diseases, those aged 45 - 64 or $\geq 65$ years exhibited age-related interactions between obesity and all-cause mortality. This suggests that health professionals may need to modify strategies and content with regard to health-related advice, health education, and health management given to obese middle-aged and above individuals, depending on their age.

\section{Conflicts of Interest}

The authors declare no conflicts of interest regarding the publication of this paper.

\section{References}

[1] Finucane, M.M., Stevens, G.A., Cowan, M.J., Danaei, G., Lin, J.K., Paciorek, C.J., et al. (2011) National, Regional, and Global Trends in Body-Mass Index since 1980: Systematic Analysis of Health Examination Surveys and Epidemiological Studies with 960 Country-Years and 9.1 Million Participants. Lancet, 377, 557-567. https://doi.org/10.1016/S0140-6736(10)62037-5

[2] Ng, M., Fleming, T., Robinson, M., Thomson, B., Graetz, N., Margono, C., et al. (2014) Global, Regional, and National Prevalence of Overweight and Obesity in Children and Adults during 1980-2013: A Systematic Analysis for the Global Bur- 
den of Disease Study 2013. Lancet, 384, 766-781. https://doi.org/10.1016/S0140-6736(14)60460-8

[3] Seidell, J.C. and Halberstadt, J. (2015) The Global Burden of Obesity and the Challenges of Prevention. Annals of Nutrition \& Metabolism, 66, 7-12.

https://doi.org/10.1159/000375143

[4] NCD Risk Factor Collaboration (2016) Trends in Adult Body-Mass Index in 200 Countries from 1975 to 2014: A Pooled Analysis of 1698 Population-Based Measurement Studies with 19.2 Million Participants. Lancet, 387, 1377-1396. https://doi.org/10.1016/S0140-6736(16)30054-X

[5] Tesfaye, F., Nawi, N.G., Van Minh, H., Byass, P., Berhane, Y., Bonita, R., et al. (2007) Association between Body Mass Index and Blood Pressure across Three Populations in Africa and Asia. Journal of Human Hypertension, 21, 28-37. https://doi.org/10.1038/sj.jhh.1002104

[6] Guh, D.P., Zhang, W., Bansback, N., Amarsi, Z., Birmingham, C.L. and Anis, A.H. (2009) The Incidence of Co-Morbidities Related to Obesity and Overweight: A Systematic Review and Meta-Analysis. BMC Public Health, 9, 88.

https://doi.org/10.1186/1471-2458-9-88

[7] Barrios, V., Escobar, C. and Calderon, A. (2010) Clinical Profile and Management of Patients with Hypertension and Chronic Ischemic Heart Disease According to BMI. Obesity, 18, 2017-2022. https://doi.org/10.1038/oby.2010.12

[8] Ostchega, Y., Hughes, J.P., Terry, A., Fakhouri, T.H. and Miller, I. (2012) Abdominal Obesity, Body Mass Index, and Hypertension in US Adults: NHANES 2007-2010. American Journal of Hypertension, 25, 1271-1278.

[9] Lee, S.K., Kim, S.H., Cho, G.Y., Baik, I., Lim, H.E., Park, C.G., et al. (2013) Obesity Phenotype and Incident Hypertension: A Prospective Community-Based Cohort Study. Journal of Hypertension, 31, 145-151. https://doi.org/10.1097/HJH.0b013e32835a3637

[10] Lavie, C.J., Alpert, M.A., Arena, R., Mehra, M.R., Milani, R.V. and Ventura, H.O. (2013) Impact of Obesity and the Obesity Paradox on Prevalence and Prognosis in Heart Failure. JACC Heart Fail, 1, 93-102. https://doi.org/10.1016/j.jchf.2013.01.006

[11] Kramer, C.K., Zinman, B. and Retnakaran, R. (2013) Are Metabolically Healthy Overweight and Obesity Benign Conditions? A Systematic Review and Meta-Analysis. Annals of Internal Medicine, 159, 758-769. https://doi.org/10.7326/0003-4819-159-11-201312030-00008

[12] Lavie, C.J., Sharma, A., Alpert, M.A., De Schutter, A., Lopez-Jimenez, F., Milani, R.V., et al. (2016) Update on Obesity and Obesity Paradox in Heart Failure. Progress in Cardiovascular Diseases, 58, 393-400. https://doi.org/10.1016/j.pcad.2015.12.003

[13] Wilson, P.W., D’Agostino, R.B., Sullivan, L., Parise, H. and Kannel, W.B. (2002) Overweight and Obesity as Determinants of Cardiovascular Risk: The Framingham Experience. Archives of Internal Medicine, 162, 1867-1872.

https://doi.org/10.1001/archinte.162.16.1867

[14] Stevens, J., Cai, J., Pamuk, E.R., Williamson, D.F., Thun, M.J. and Wood, J.L. (1998) The Effect of Age on the Association between Body-Mass Index and Mortality. New England Journal of Medicine, 338, 1-7. https://doi.org/10.1056/NEJM199801013380101

[15] Calle, E.E., Thun, M.J., Petrelli, J.M., Rodriguez, C. and Heath Jr., C.W. (1999) Body-Mass Index and Mortality in a Prospective Cohort of U.S. Adults. New England Journal of Medicine, 341, 1097-1105. 
https://doi.org/10.1056/NEJM199910073411501

[16] McTigue, K., Larson, J.C., Valoski, A., Burke, G., Kotchen, J., Lewis, C.E., et al. (2006) Mortality and Cardiac and Vascular Outcomes in Extremely Obese Women. JAMA, 296, 79-86. https://doi.org/10.1001/jama.296.1.79

[17] Neovius, M., Sundstrom, J. and Rasmussen, F. (2009) Combined Effects of Overweight and Smoking in Late Adolescence on Subsequent Mortality: Nationwide Cohort Study. BMJ, 338, b496. https://doi.org/10.1136/bmj.b496

[18] Whitlock, G., Lewington, S., Sherliker, P., Clarke, R., Emberson, J., Halsey, J., et al. (2009) Body-Mass Index and Cause-Specific Mortality in 900000 Adults: Collaborative Analyses of 57 Prospective Studies. The Lancet (London, England), 373, 1083-1096. https://doi.org/10.1016/S0140-6736(09)60318-4

[19] Berrington de Gonzalez, A., Hartge, P., Cerhan, J.R., Flint, A.J., Hannan, L., MacInnis, R.J., et al. (2010) Body-Mass Index and Mortality among 1.46 Million White Adults. The New England Journal of Medicine, 363, 2211-2219. https://doi.org/10.1056/NEJMoa1000367

[20] Park, S.Y., Wilkens, L.R., Murphy, S.P., Monroe, K.R., Henderson, B.E. and Kolonel, L.N. (2012) Body Mass Index and Mortality in an Ethnically Diverse Population: The Multiethnic Cohort Study. European Journal of Epidemiology, 27, 489-497. https://doi.org/10.1007/s10654-012-9695-5

[21] Orpana, H.M., Berthelot, J.M., Kaplan, M.S., Feeny, D.H., McFarland, B. and Ross, N.A. (2010) BMI and Mortality: Results from a National Longitudinal Study of Canadian Adults. Obesity, 18, 214-218. https://doi.org/10.1038/oby.2009.191

[22] Zheng, W., McLerran, D.F., Rolland, B., Zhang, X., Inoue, M., Matsuo, K., et al. (2011) Association between Body-Mass Index and Risk of Death in More than 1 Million Asians. The New England Journal of Medicine, 364, 719-729. https://doi.org/10.1056/NEJMoa1010679

[23] Flegal, K.M., Kit, B.K., Orpana, H. and Graubard, B.I. (2013) Association of All-Cause Mortality with Overweight and Obesity Using Standard Body Mass Index Categories: A Systematic Review and Meta-Analysis. JAMA, 309, 71-82. https://doi.org/10.1001/jama.2012.113905

[24] Carmienke, S., Freitag, M.H., Pischon, T., Schlattmann, P., Fankhaenel, T., Goebel, H., et al. (2013) General and Abdominal Obesity Parameters and Their Combination in Relation to Mortality: A Systematic Review and Meta-Regression Analysis. European Journal of Clinical Nutrition, 67, 573-585. https://doi.org/10.1038/ejen.2013.61

[25] Patel, A.V., Hildebrand, J.S. and Gapstur, S.M. (2014) Body Mass Index and All-Cause Mortality in a Large Prospective Cohort of White and Black U.S. Adults. PLOS ONE, 9, e109153. https://doi.org/10.1371/journal.pone.0109153

[26] Aune, D., Sen, A., Prasad, M., Norat, T., Janszky, I., Tonstad, S., et al. (2016) BMI and All Cause Mortality: Systematic Review and Non-Linear Dose-Response Meta-Analysis of 230 Cohort Studies with 3.74 Million Deaths among 30.3 Million Participants. BMJ, 353, i2156. https://doi.org/10.1136/bmj.i2156

[27] Cheng, F.W., Gao, X., Mitchell, D.C., Wood, C., Still, C.D., Rolston, D., et al. (2016) Body Mass Index and All-Cause Mortality among Older Adults. Obesity, 24, 2232-2239. https://doi.org/10.1002/oby.21612

[28] Stessman, J., Jacobs, J.M., Ein-Mor, E. and Bursztyn, M. (2009) Normal Body Mass Index Rather than Obesity Predicts Greater Mortality in Elderly People: The Jerusalem Longitudinal Study. Journal of the American Geriatrics Society, 57, 2232-2238. https://doi.org/10.1111/j.1532-5415.2009.02567.x 
[29] Hamer, M. and Stamatakis, E. (2013) Overweight and Obese Cardiac Patients Have Better Prognosis Despite Reporting Worse Perceived Health and More Conventional Risk Factors. Preventive Medicine, 57, 12-16. https://doi.org/10.1016/j.ypmed.2013.02.012

[30] Clark, A.L., Fonarow, G.C. and Horwich, T.B. (2014) Obesity and the Obesity Paradox in Heart Failure. Progress in Cardiovascular Diseases, 56, 409-414. https://doi.org/10.1016/j.pcad.2013.10.004

[31] Goyal, A., Nimmakayala, K.R. and Zonszein, J. (2014) Is There a Paradox in Obesity? Cardiology in Review, 22, 163-170. https://doi.org/10.1097/CRD.0000000000000004

[32] Gupta, P.P., Fonarow, G.C. and Horwich, T.B. (2015) Obesity and the Obesity Paradox in Heart Failure. Canadian Journal of Cardiology, 31, 195-202. https://doi.org/10.1016/j.cjca.2014.08.004

[33] Oga, E.A. and Eseyin, O.R. (2016) The Obesity Paradox and Heart Failure: A Systematic Review of a Decade of Evidence. Journal of Obesity, 2016, Article ID: 9040248. https://doi.org/10.1155/2016/9040248

[34] Yang, W., Li, J.P., Zhang, Y., Fan, F.F., Xu, X.P., Wang, B.Y., et al. (2016) Association between Body Mass Index and All-Cause Mortality in Hypertensive Adults: Results from the China Stroke Primary Prevention Trial (CSPPT). Nutrients, 8, E384. https://doi.org/10.3390/nu8060384

[35] Hamzeh, N., Ghadimi, F., Farzaneh, R. and Hosseini, S.K. (2017) Obesity, Heart Failure, and Obesity Paradox. The Journal of Tehran University Heart Center, 12, $1-5$.

[36] Chang, V.W., Kenneth, M.L., David, R.W. and Theodore, J.I. (2017) The Obesity Paradox and Incident Cardiovascular Disease: A Population-Based Study. PLoS ONE, 12, e0188636. https://doi.org/10.1371/journal.pone.0188636

[37] Janssen, I. (2007) Morbidity and Mortality Risk Associated with an Overweight BMI in Older Men and Women. Obesity, 15, 1827-1840. https://doi.org/10.1038/oby.2007.217

[38] Bender, R., Jockel, K.H., Trautner, C., Spraul, M. and Berger, M. (1999) Effect of Age on Excess Mortality in Obesity. JAMA, 281, 1498-1504. https://doi.org/10.1001/jama.281.16.1498

[39] Stevens, J., Cai, J., Juhaeri Thun, M.J., Williamson, D.F. and Wood, J.L. (1999) Consequences of the Use of Different Measures of Effect to Determine the Impact of Age on the Association between Obesity and Mortality. American Journal of Epidemiology, 150, 399-407. https://doi.org/10.1093/oxfordjournals.aje.a010019

[40] Flegal, K.M., Graubard, B.I., Williamson, D.F. and Cooper, R.S. (2011) Reverse Causation and Illness-Related Weight Loss in Observational Studies of Body Weight and Mortality. American Journal of Epidemiology, 173, 1-9. https://doi.org/10.1093/aje/kwq341

[41] World Health Organization (2000) Obesity: Preventing and Managing the Global Epidemic: Report of a WHO Consultation. WHO Technical Report Series No. 894.

[42] Flegal, K.M., Graubard, B.I., Williamson, D.F. and Gail, M.H. (2007) Impact of Smoking and Preexisting Illness on Estimates of the Fractions of Deaths Associated with Underweight, Overweight, and Obesity in the US Population. American Journal of Epidemiology, 166, 975-982. https://doi.org/10.1093/aje/kwm152

[43] Flegal, K.M., Graubard, B.I. and Yi, S.W. (2017) Comparative Effects of the Restriction Method in Two Large Observational Studies of Body Mass Index and Mortality among Adults. European Journal of Clinical Investigation, 47, 415-421. 
https://doi.org/10.1111/eci.12756

[44] Janssen, I. and Mark, A.E. (2007) Elevated Body Mass Index and Mortality Risk in the Elderly. Obesity Reviews, 8, 41-59. https://doi.org/10.1111/j.1467-789X.2006.00248.x

[45] Kuk, J.L. and Ardern, C.I. (2009) Influence of Age on the Association between Various Measures of Obesity and All-Cause Mortality. Journal of the American Geriatrics Society, 57, 2077-2084. https://doi.org/10.1111/j.1532-5415.2009.02486.x

[46] Ng, T.P., Jin, A., Chow, K.Y., Feng, L., Nyunt, M.S.Z. and Yap, K.B. (2017) Age-Dependent Relationships between Body Mass Index and Mortality: Singapore Longitudinal Ageing Study. PLoS ONE, 12, e0180818.

https://doi.org/10.1371/journal.pone.0180818

[47] Keith, S.W., Fontaine, K.R., Pajewski, N.M., Mehta, T. and Allison, D.B. (2011) Use of Self-Reported Height and Weight Biases the Body Mass Index-Mortality Association. International Journal of Obesity, 35, 401-408.

https://doi.org/10.1038/ijo.2010.148

[48] Veronese, N., Li, Y., Manson, J.E., Willett, W.C., Fontana, L. and Hu, F.B. (2016) Combined Associations of Body Weight and Lifestyle Factors with All Cause and Cause Specific Mortality in Men and Women: Prospective Cohort Study. BMJ, 355, i5855. https://doi.org/10.1136/bmj.i5855 